УДК 911.3

https://doi.org/10.34142/2313-2345.2019.56.16

О. Г. Стадник

професор кафедри географії та методики викладання географії Харківського національного педагогічного університету імені Г.С.Сковороди

ORCID 0000-0002-9207-7675

В. В. Піткевич

завідувач кафедри географії та методики викладання географії Харківського національного педагогічного університету імені Г.С.Сковороди ORCID 0000-0002-3350-0576

\title{
СТВОРЕННЯ ШКІЛЬНИХ ЗАСОБІВ НАВЧАННЯ ГЕОГРАФІЇ В ЧАСИ СТАНОВЛЕННЯ РАДЯНСЬКОЇ ОСВІТНЬОЇ СИСТЕМИ
}

Стаття присвячена питанням створення системи шкільних засобів навчання, які використовувались при викладанні географії в середніх закладах освіти з середини 30-х до середини 50-х рр. ХХ ст. 3'ясовано, шьо на підготовку засобів навчання вплинули політичні і культурно-історичні умови того часу. Зокрема, постанови ЦК ВКП (б) «Про початкову і середню школу» (5 вересня 1931 р.) $i$ «Про навчальні програми і режим у початковій і середній школі» (25 серпня 1932 р.), які обумовили радикальний поворот в шкільній освіті $і$ на десятиліття вперед визначили розвиток шкільної освіти у вигляді нормативно-уніфікованої моделі. Необхідність за- 
безпечити виконання завдань на практиці спочатку обумовила підготовку програм икільних предметів, потім стабільних підручників, посібників, зокрема, з методики викладання географії та окремих їі шкільних курсів, а згодом створенні (в загальних рисах) системи засобів навчання. Вона включала програмно-нормативні (програми), навчальні (підручники, географічні карти, атласи, контурні карти, картини, макети, колекцій гірських порід і мінералів, гербарії, діапозитиви, навчальні кінострічки, прилади, обладнання), навчально-методичні (методичні посібника для вчителів різного типу, періодичні журнали) і додаткові, підтримуючі (хрестоматії, довідники, науково-популярні видання та) засоби. Центральне місие в иій системі зайняли програми і створені на їх основі стабільні підручники з усіх шкільних курсів. Їх текст був ідеологічно витриманим і виконував функиію виховання в дусі комуністичних ідей. Зросла кількість і якість методичних посібників, географічних карт, з'явились науково-популярні та навчальні кінострічки.

Створення системи шкільних засобів навчання на десятиліття вперед визначило розвиток шкільної географії та методики у вигляді нормативно-уніфікованої моделі. Склалися умови для розробки науковопрактичних питань з проблем конструювання $і$ використання системи засобів навчання географії. В той же час иентралізація та ідеологізація освіти обумовили різке зниження творчих пошуків і ініціативи на місиях.

Ключові слова: школа, засоби навчання, географія, підручник, методичний посібник, географічна карта, атлас, словник.

The article is devoted to the creation of a school system of teaching that was used in teaching geography in secondary education institutions from the mid-30's to the mid-1850's. It was found out that the training of teaching aids was influenced by the political, cultural and historical conditions of the time. In particular, the decree of the Central Committee of the CPSU (b) "On Elementary and Secondary School" (September 5, 1931) and "On Educational Programs and Mode in Elementary and Secondary School" (August 25, 1932), which led to a radical turn in school education and for decades ahead determined the development of school education in the form of a normative-unified model. The need to ensure that the tasks were carried out in practice initially led to the preparation of programs for school subjects, then on stable textbooks, manuals, in particular on the methodology of teaching geography and its individual school courses, and subsequently the creation of (in general terms) learning systems. It included program-normative (programs), educational (textbooks, geographic maps, atlases, contour maps, paintings, mock-ups, collections of rocks and minerals, herbaria, slides, educational films, instruments, equipment), teaching aids (manuals for teachers of different types, periodicals) and additional supporters (textbooks, reference books, popular science publications and tools). The central place in this system was taken by the programs and created on their basis stable textbooks from all school courses. Their text was ideologically sustained and served as a function of education in the spirit of communist ideas. The number and quality of methodical manuals, geographic maps has increased, and popular science and educational films have appeared.

Creation of a system of school means of learning for decades to come determined the development of school geography and methodology in the form of a standardized model. There were conditions for the development of scientific and practical issues on the design and use of the system of training geography. At the same time, the centralization and ideologization of education led to a sharp decline in creative searches and initiatives on the ground.

Key words: school, teaching aids, geography, textbook, methodological manual, geographic map, atlas, dictionary.

Постановка проблеми. Основою для статті стало недостатнє висвітлення проблем створення шкільних засобів навчання в часи становлення радянської системи освіти (середина 30-х - середина 50-х рр. ХХ ст.), які виступають важливим джерелом історикометодичної інформації. Постає необхідність виявити чинники, які обумовили появу перших стандартних програм шкільних предметів, потім серії постійних базових підручників, методичних посібників, зокрема, зі шкільної географії та окремих іiі курсів, а згодом створення системи засобів навчання. 3'ясувати зміст та структуру найважливіших 3 них. Визначити склад (в загальних рисах) системи засобів навчання на прикладі шкільної географії.

Аналіз основних досліджень і публікацій, в яких започатковано розв'язання даної проблеми. Питання історії становлення і розвитку шкільної географії та іiї за- безпечення засобами навчання розглядалися у працях М. Баранського, О. Борзова, А. Баркова, Л. Весіна, Н. Гупана, Я. Жупанського, Л. Мельничук, С. Поздняк, І. Шоробури. Зокрема, Л. Вєсін зробив історичний огляд підручників загальної та російської географії, виданих в період 1710-1876 рр., аналіз шкільних підручників географії більш ніж за піввіковий період (1876-1934 роки) провів М. Баранський, становлення та розвиток шкільної географічної освіти в Україні (XIX-XX століття) досліджено I. Шоробурою, шкільна географія в Україні на початку XX століття (1900-1917 рр.) розглянута Л. Мельничук. Разом із тим питання створення шкільних засобів навчання в часи становлення радянської освітньої системи розглянуті недостатньо.

Мета статті - розкрити питання вирішення проблеми створення шкільних засо- 
бів навчання в часи становлення радянської системи освіти.

Виклад основного матеріалу. На початку $30-$ - років проблемами освіти почав займатися Відділ шкіл ЦК ВКП(б), яким безпосередньо керував Й. Сталін. Він особисто ініціював, ретельно вивчав, рецензував основоположні освітні документи, що без обговорення 3 педагогічною громадськістю приймалися не Наркоматом освіти, а ЦК ВКП(б) [Березівська 2009]. Серед основних документів були постанови «Про початкову i середню школу» (5 вересня 1931 р.) і «Про навчальні програми і режим у початковій і середній школі» (25 серпня 1932 р.) які обумовили радикальний поворот в шкільній освіті: від експериментування й пошуків до впорядкування та уніфікації на основі комуністичної ідеології.

Розпочалась робота над єдиною програмою 3 географії. Під керівництвом М. Баранського, в iī розробці прийняли участь О. Барков, Б. Камінський, С. Некрасов, О. Половінкін. Згідно 3 постановою «Про викладання географії в початковій і середній школі СРСР» (15 травня 1934 р.) географія увійшла в навчальні плани середньої школи і викладалася в 5-9 класах (у початковій школі - у 3-4 класах). Повертаючи традиційне значення підручника та розуміючи важливість інших засобів, значну частину документу присвятили саме їх підготовці. Центральним органам освіти пропонувалося видати на допомогу вчителям географії хрестоматії, методики викладання, бібліографічний покажчик книг та географічний журнал для вчителів (стосовно підручників було вказано класи, автори чи авторські колективи); на місцях (в союзних республіках) планувалося видати невелику серію книг для цікавого читання учнів 3 географії (біографії великих мандрівників, розповіді $з$ життя окремих країн і народів, популярні описи найважливіших подорожей і т.п.); за заявками Народних комісаріатів освіти мало розпочатися видання географічних карт, атласів, картин, таблиць та інших навчальних посібників із географії. «На державному рівні визначалися: структура шкільного курсу, розподіл навчального часу за ступенями навчання; давалися ре- комендації до програм та підручників. 3 цього часу починається новий етап створення та використання засобів навчання географії, як предмета, що зайняв важливе місце в навчальних планах школи» [Стадник 2015].

Із 1935 р. починають видавати підручники з географії. Їх готували визнані вченігеографи і методисти: О. Барков, М. Баранський, І. Вітвер, Г. Іванов, О. Половінкін, С. Чефранов, В. Ерделі.

Підручник для 5-х класів із фізичної географії в 1935 р. оприлюднили О. Барков i О. Половінкін. Він витримав 15 перевидань і прослужив близько 20 років. Хоча за структурою він досить близький до підручників пізнішого періоду, але має суттєві концептуальні відмінності (передусім це відноситься до розгляду геосфер у взаємозв'язку і взаємодіiі) [Барков 1951].

Текст підручника доступний, він легко i 3 цікавістю читається. Автори використовували порівняння і доказовість на прикладі конкретних географічних об'єктів. Звертає на себе увагу велика кількість карт, картосхем, схем, фотографій і рисунків. На них $\epsilon$ посилання в основному тексті. До недоліків можна віднести недосконалі апарати організації засвоєння (відсутні запитання i завдання після параграфів) та орієнтування.

У тому ж 1935 р. вийшли два підручника М. Баранського: «Физическая география СССР» для 7-го класу (7 видань, останнє - в 1943 р.) і «Экономическая география СССР» для 8-го класу (16 видань, останнє в 1955 р.). У 1952 р. останній було удостоєно Державної премії СРСР. Цей підручник складався зі вступу і двох частин. Перша, під назвою «Огляд СРСР в цілому» (за виданням 1951 р.), включав загальну характеристику народного господарства, географію промисловості, сільського господарства i транспорту. Друга, найбільша за обсягом (понад 300 сторінок $з$ 424), під назвою « $\mathrm{Pa}$ йонний огляд СРСР», складалась із характеристик окремих районів (регіони Росії, республіки або їх угрупування). При цьому давалась як загальна характеристика Росії, так і 13 iї регіонів, виділених з урахуванням територіально-адміністративного поділу [Баранский, 1951]. Таким чином, в основу 
підручника було покладено регіональнокраїнознавчий принцип.

Аналіз показує, що в підручниках було поєднано традиції попередніх періодів і сучасні досягнення географічної науки та педагогіки. Близько 20 років вони утворювали єдиний, стабільний комплекс, який забезпечував викладання географії в школі, починаючи 3 елементарного уявлення про предмет, до економічної географії зарубіжних країн (при цьому треба мати на увазі, що на їх еволюцію та оновлення негативно вплинула війна i наступний період відбудови господарства). Основний текст підручників 3 одного боку був доступним і логічним, 3 іншого - науковим і доказовим. У ньому, в різній мірі, використовувалися описи, пояснення, узагальнення, порівняння, аналіз, висновки. Зазвичай, велика увага приділялася різноманітним ілюстраціям, зокрема картографічному матеріалу. Карти, включаючи кольорові, і картосхеми ув'язувалися 3 основним текстом. В той же час відсутність єдиних методичних вимог до побудови текстових та позатекстових компонентів (що пояснюється недостатнім теоретичним обгрунтуванням підручникотворення) обумовила істотну різницю в підходах, призвела до суттєвих недоліків в частині 3 них: відсутність апарату організації засвоєння (це була інша крайність після «робочих книг» перевантажених цим елементом), відсутність додаткового та пояснювального текстів, додатків, словників, посилань на ілюстрації та деяких інших елементів апарату орієнтування [Стадник 2016]. В підручниках не приділялася увага загальнолюдським й національним цінностям; нав'язувалася комуністична ідеологія; не розглядалися наукові теорії, які не підтримувалися партією; не об'єктивно оцінювалися досягнення СРСР, а з часом і країн народної демократії. До того ж наявність стабільних підручників різко скоротила можливості творчих пошуків у підручникотворенні. У першу чергу це вплинуло на даний процес на місцях, зокрема в Україні.

Необхідність забезпечити виконання нових програм на практиці зумовила підготовку посібників 3 методики викладання географії. Зокрема виходять: «Методика физической географии» (1938) О. Поло- вінкіна, «Методика преподавания физической географии» (1939) В. Буданова, «Методика географии для учителей начальной школы» (1939) О. Половінкіна та В. Грузинської, «Методика преподавания географии» (1939) колективу авторів під редакцією В. Ерделі. У цих посібниках повно та різнобічно висвітлювалися методи викладання фізичної географії, але переважно як способи і прийоми, вироблені шкільною практикою [Бибик 1968]. У 1946 р. М. Баранський видав першу методику викладання економічної географії - «Очерки школьной методики экономической географии». На відміну від методики фізичної географії, iї довелося створювати без використання раніше накопиченого досвіду.

Одним 3 перших посібників повоєнного часу була методика М. Куразова. Вона мала чітку структуру і включала чотири частини. У першій ішлося про те, що таке методика географії, про розуміння географії як науки і як навчального предмету, про зміст і місце курсу географії в початковій школі. Відзначимо, що автор приділив увагу підручниками попереднього періоду, відзначивши «сухість викладу», «недостатність фізико-географічного матеріалу», «перевантаження... с статистично-економічним матеріалом і загальними схемами» [Куразов 1950]. У другій частині розглянуто основні принципи викладання географії в початковій школі. У третій обговорювались форми і методи викладання географії в початковій школі. Четверту було присвячено позакласній роботі з географії в початковій школі.

Посібник В. Ерделі «Методика преподавания географии» (1949) цікавий тим, що питання методології методики географії у ньому вперше було виділено у самостійний розділ [Эрдели 1949]. На думку автора основними завданнями методики виступають: теоретичне обгрунтування програм; встановлення методів ідейно-політичного розвитку учнів (розвиток матеріалістичного світогляду, виховання радянського патріотизму і комуністичної моралі); експериментальна перевірка якості посібників (підручників, карт, атласів, картин і т. д.) [Эрдели 1949]. $\mathrm{y}$ посібнику також наведено оцінку розвитку методичних ідей дорадянського часу. 
Враховуючи тривалий період негативного ставлення до цього досвіду, підхід авторів слід визнати прогресивним [Поздняк 2006].

Кілька посібників присвячених методиці викладання різних шкільних курсів було підготовлено А. Бібік: «Методика преподавания географии в 6 классе семилетней школы» (1949), «Методика преподавания географии частей света» (1952), «Методика преподавания экономической географии зарубежных стран» (1958). Так, у посібнику з географії частин світу розглянуто як загальнометодичні, так і прикладні питання, зокрема методи й засоби навчання. Інший характер мав об'ємний посібник для вчителів «География СССР» (1955) підготовлений групою авторів під редакцією М. Лялікова і М. Солнцева. 3 усіх питань методики в ньому розглянуто тільки зміст відповідного курсу. У посібнику, як і в чинному шкільному підручнику, дві частини «Загальний огляд СРСР» та «Огляд республік СРСР», включаючи райони РРФСР. Комплексна характеристика Української СРСР займає 43 сторінки. У ній докладно розглянуті всі три складові: природа (включаючи геологічну будову), населення і господарство [Ляликова 1955].

Питання методики викладання економічної географії СРСР розробляв доцент Київського університету В. Поданчук. У 1954 р. вийшли його «Нариси 3 методики викладання економічної географії СРСР в середній школі». На відміну від більшості інших посібників в ньому розглядаються тільки питання що стосуються викладання курсу економічної географії СРСР. В першій частині основну увагу приділено методиці роботи з географічними картами, цифровими показниками та підручником економічної географії СРСР. В другій автор дав рекомендації щодо методики викладання окремих тем курсу економічної географії СРСР (характеристика народного господарства СРСР у цілому, промисловість, сільське господарство, транспорт) [Поданчук 1954].

Розуміючи важливість єдності географічної науки автор провів ідею тісних зв'язків економічної на фізичної географії, в тому числі на основі комплексного використання карт атласу. «Треба навчити учнів пов'язувати матеріал підручника з набутими вже знаннями. Наприклад, опрацьовуючи теми «Енергетика», «Чорна та кольорова металургія», варто послатись на знання учнів про корисні копалини СРСР з курсу VII класу... зіставивши карту густоти посівів, що наводиться в підручнику (рис. 16, стор. 60), з картами кліматичною і грунтів СРСР, що $є$ в атласі, учні зможуть самостійно прийти до висновку, чому в тій чи іншій природній зоні такий, а не інший напрям розвитку сільського господарства. Таке зіставлення дає можливість пов'язувати фізико-географічний матеріал, відомий учням 3 курсу VII класу, 3 економікогеографічним, що вивчається в VIII класі. Тут учні привчаються бачити об'єкти і явища в певному взаємозв'язку і на основі цього приходити до конкретних висновків» [Поданчук 1954].

У другій частині автор дав рекомендації щодо методики викладання окремих тем курсу економічної географії СРСР (характеристика народного господарства СРСР в цілому, промисловість, сільське господарство, транспорт). При цьому він застосував увесь методичний апарат підручника: текст, питання і завдання, карти, картосхеми, картодіаграми, картограми, діаграми, графіки, таблиці, фотографії.

В. Поданчук продовжував роботу над питаннями методики викладання економічної географії СРСР і в 1959 р. опублікував ще більш грунтовну роботу «Методика викладання економічної географії СРСР в середній школі». В ній значно глибше висвітлено питання, про які йшлось в попередньому посібнику i розглянуто нові проблемні області. В першу чергу це стосується районного огляду СРСР, якому автор присвятив окрему - третю частину посібника [Поданчук 1959].

Після постанови 1934 р. стрімко зросла увага до географічних карт. «Географічна специфіка» того часу полягала в тому, що географію сприймали як «науку про карту і природу». Забезпеченню навчального процесу цими засобами в значній мірі сприяло створення 10 найбільш необхідних школі стінних карт (материки, півкулі, політичні карти світу та Європи, фізична і політична карти СРСР). Ця робота, в якій бра- 
ли участь В. Ерделі, В. Буданов, О. Борзов, М. Барансякий, інші відомі фахівці була виконана в 1938 р. Набір отримав робочу назву «урядові карти». Їх виготовлення йшло за замовленням і під регулярним контролем Раднаркому.

Окрім даних стінних карт, картографи працювали над набором тематичних стінних карт (карта природних зон, кліматична, рослинна), контурними картами, атласами. Першим було видано «Географічний атлас для III i IV класів початкової школи», слідом за ним - атлас для V i VI класів, а потім - «Географічний атлас СРСР для середньої школи» (Бибик, 1968). Атлас для III i IV класів початкової школи вийшов під редакцією В. Ерделі, який незабаром видав посібник, присвячений рекомендаціям для роботи з цим засобом навчання.

Для забезпечення належного рівня використання навчальних карт в практиці школи, даному питанню було приділено велику увагу в загальнометодичних посібниках i роботах 3 методики викладання окремих шкільних курсів. Також це зумовило створення вузькоспеціальних методичних посібників, які за визначенням В. Максаковського присвячено «наскрізним» аспектам навчання географії. Так, у 1948 р. В. Буданов видав роботу «Карта в преподавании географии», в 1949 р. М. Сгоров оприлюднив посібник «Топографическая карта» (кілька перевидань, в тому числі, українською мовою), в 1954 р. І. Заславський видав посібник «Карта на уроках геогpaфiï».

У 1955 р. вийшла робота групи авторів, під редакцією І. Самойлова «Наглядность в преподавании географии». У ній визначалися важливі теоретичні положення відносно ролі окремих засобів навчання в забезпеченні наочності у шкільній практиці та давалися практичні рекомендації з їх використання (Самойлова, 1955). Кілька разів перевидавалась грунтовна робота О. Половінкіна «География и рисование» (1949).

3 інших видань, насамперед, відзначимо «Словарь-справочник по физической географии», підготовлений О. Барковим. Він витримав кілька перевидань (перше в 1940 р., останнє - в 1958 р.). М. Боднарський підготував «Словарь геогра- фических названий» (1954). У ньому він помістив «пояснення назв», наявних у підручниках географії для середньої школи, а також ряд суміжних.

У 1933 р. було організовано видавництво «Детгиз» («Дитяча література»), серед найбільш відомих серій якого відзначимо «Шкільну бібліотеку» i «Бібліотеку пригод та наукової фантастики». В них видавалися книги, в тому числі науковопопулярні, які мали географічний зміст. Брошури про країни та регіони світу 3 1950 р. друкувалися в серії Державного видавництва географічної літератури «Біля карти світу».

Ряд робіт підготували відомі географи. Так, С. Григор'єв доповнив і перевидав посібник для вчителів «Вокруг Южного полюса» (перше видання - 1906, третє - в 1937 р.). Робота була добре ілюстрована численними фотографіями і схемами. Талант вченого-геолога, популяризатора знань про Землю та письменника об'єднав В. Обручев. Його перу належать багатотомні монографії, підручники, науково популярні роботи й науково-фантастичні романи, тематика більшості з яких була пов'язана 3 подорожами та дослідженнями Землі.

У 1930-1940 pp. вчителі отримали «велику кількість кінострічок різних жанрів, серед яких були фільми про подорожі, документально-описові, етнографічні, що розповідали про капіталістичну економіку і економіко-географічні проблеми СРСР» [Черепинский 1989].

У середині XX ст. був накопичений великий і різноманітний масив навчальнонаочних посібників, крім карт, це були картини, макети, колекцій гірських порід і мінералів, гербарії, діапозитиви; вчителі почали використовувати нову техніку й обладнання; масового поширення набула кабінетна система. У 1950 р. було зроблено першу спробу класифікації засобів навчання географії із урахуванням їх внутрішніх властивостей. О. Григор'єв виділив дві групи засобів навчання [Григорьев 1950].

Висновки. У розглянутий період шкільна географія була поставлена на тверду наукову та методичну основу. Зокрема, це знайшло відображення у практичному створенні (в загальних рисах) системи засобів 

тивні, навчальні, навчально-методичні та додаткові, підтримувальні засоби.

Маючи високий науковий рівень, частина підручників мала недоліки методичного характеру. Це обмежувало можливості вчителя, негативно впливало на протікання та результативність навчального процесу.

За змістом серед методичних посібників позначилася диференціація на:

1) загальнометодичні;

2) присвячені методиці викладання декількох (початкова школа, фізична географія, економічна географія) і одного шкільного курсу (географія частин світу, економічна географія СРСР);

3) які розглядали «наскрізні» аспекти навчання географії (переважно використання в навчальному процесі засобів наочності, насамперед карт).

У той же час не вистачало методичних посібників, які б вказували на шляхи реалізації вимог програми шляхом організації та проведення уроків по всьому курсу. навчання, що включала програмно-норма-

Різко зросла кількість і якість загальногеографічних і тематичних карт (стінних, у вигляді додатків до підручників, у вигляді атласів для окремих або кількох класів), а також вимоги до умінь користуватися ним (розуміти, читати).

Практичне створення системи засобів навчання географії стало однією з головних причин того, що «викладання географії в школі після 1934 р. упродовж багатьох років неухильно удосконалювалося» (Бибик, 1968).

Перспективи подальших розвідок убачаємо в подальших дослідженнях поступового удосконалення системи засобів навчання шкільної географії в умовах радянської освітньої системи, яке відбувалось на тлі розвитку теоретико-методологічних основ методики навчання предмету. Також необхідно розглянути співвідношення факторів, які впливали на створення нових та еволюцію існуючих засобів навчання географії.

\section{ЛІТЕРАТУРА}

Барков, А. С., Половинкин, А. А. (1951). Физическая география. Учебник для 5-го класса семилетней и средней школь. Москва: Учпедгиз.

Баранский, Н.Н. (1951). Экономическая география СССР. Учебник для 8 класса средней школь.. Издание двенадйатое. М.: Учпедгиз.

Березівська, Л.Д. (2009). Організаційно-педагогічні засади реформування шкільної освіти в Україні у XX столітmі. (Автореф. дис... д-ра пед. Наук). Київ: Ін-т педагогіки НАПН України.

Бибик, А. Е. и др. (1968) Методика обучения географии в средней школе. М.: Просвещение, 390.

Григорьев, А. Л. (1950) Географический кабинет. М., 155.

Эрдели, В. Г. (1949). Методика преподавания географии: пособие для учит, ин-тов. М.: Учпедгиз, 322.

Куразов, Н. Ф. (1950). Методика преподавания географии: пособие для учителей. М.: Учпедгиз, 222.

Ляликова, Н. И., Солнцева, Н. А. (1955). География СССР: пособие для учителей. М.: Учпедгиз, 535.
Поздняк, С. Н. (2006) Становление и тенденции развития методики обучения географии как науки в России. (Дис... д-ра пед. Наук). М., 429.

Поданчук, В. Д. (1954). Нариси з методики викладання економічної географії СРСР в середній школі. K., 160.

Поданчук, В. Д. (1959). Методика викладання економічної географї СРСР в середній школі. Київ: Радянська школа, 269.

Самойлова, И. И. (1955) Наглядность в преподавании географии: сборник в помощь учителю. (Акад. пед. наук РСФСР. Пед. б-ка учителя. Ин-т методов обучения). М.: Акад. Пед. наук РСФСР, 152.

Стадник, О. Г. (2015). Перше покоління стабільних, безальтернативних підручників географіі: Харків: Новий Колегіум, 1, 58-61.

Стадник, О. Г. (2016). Підручники географії в період педагогічних пошуків та іновацій. Харків: Новий колегіум, 1 (83), 66-70.

Черепинский, С. И. (1989). Учебное кино: история становления, современное состояние, тенденции развития дидактических идей. Воронеж: Воронеж. гос. ун-т., 168.

\section{REFERENCES}

Barkov, A. S., Polovynkyn, A. A. (1951). Fyzycheskaia heohrafyia. Uchebnyk dlia 5-ho klassa semyletnei $y$ srednei shkol [Physical geography. Textbook for the 5th grade of the seven-year and high school]. Moskva: Uchpedhyz [in Russian]. 
Baranskyi, N.N. (1951). Эkonomycheskaia heohrafyia SSSR. Uchebnyk dlia 8 klassa srednei shkol [Economic geography of the USSR. Textbook for 8th grade high school]. Moskva: Uchpedhyz [in Russian].

Berezivska, L.D. (2009). Orhanizatsiino-pedahohichni zasady reformuvannia shkilnoi osvity v Ukraini u XX stolitti [Organizational and Pedagogical Principles of Reforming School Education in Ukraine in the 20th Century]. Extendent abstract of Doctor's thesis. Kyiv: [in Ukrainian].

Bybyk, A. E. (1968) Metodyka obuchenyia heohrafyy $v$ srednei shkole [Methods of teaching geography in high school]. Moskva: Prosveshchenye [in Russian].

Hryhorev, A. L. (1950) Heohrafycheskyi kabynet. [Geographical Cabinet]. Moskva. [in Russian].

Erdely, V.H. (1949). Metodyka prepodavanyia heohrafyy: posobye dlia uchyt, yn-tov [Methods of teaching geography: a manual for teaches, in-comrade]. Moskva: Uchpedhyz [in Russian].

Kurazov, N.F. (1950). Metodyka prepodavanyia heohrafyy: posobye dlia uchytelei [Methods of teaching geography: a manual for teachers.] Moskva: Uchpedhyz [in Russian].

Lialykova, N. Y., Solntseva, N.A. (1955). Heohrafyia SSSR: posobye dlia uchytelei. [Geography of the USSR: a manual for teachers] Moskva: Uchpedhyz [in Russian].

Pozdniak, S.N. (2006) Stanovlenye y tendentsyy razvytyia metodyky obuchenyia heohrafyy kak nauky $\mathrm{v}$ Rossyy [Formation and development trends of teaching geography as a science in Russia.] Doctor's thesis. Moskva [in Russian].

Podanchuk, V. D. (1954). Narysy z metodyky vykladannia ekonomichnoi heohrafii SRSR v serednii shkoli [Draw on the methodology of the geographic economic geography of the Soviet Union in the middle school]. Kyiv. [in Ukrainian].

Podanchuk, V.D. (1959). Metodyka vykladannia ekonomichnoi heohrafii SRSR v serednii shkoli [Methods of invigorating economic geography of the USSR in secondary schools]. Kyiv: Radianska shkola [in Ukrainian].

Samoilova, Y.Y. (1955) Nahliadnost $v$ prepodavanyy heohrafyy: sbornyk $v$ pomoshch uchyteliu. [Visibility in the teaching of geography: a collection to help the teacher]. Moskva: Akad. Ped. nauk RSFSR [in Russian].

Stadnyk, O.H. (2015). Pershe pokolinnia stabilnykh, bezalternatyvnykh pidruchnykiv heohrafii [First generation of stable, unopposed alternative geographers]. Novyi Kolehium, 1, 58-61 [in Ukrainian].

Stadnyk, O.H. (2016). Pidruchnyky heohrafii v period pedahohichnykh poshukiv ta inovatsii. [Geographers in the period of pedagogical acquistions and innovations Kharkiv]. Novyi kolehium, 1 (83), 66-70 [in Ukrainian].

Cherepynskyi, S.Y. (1989). Uchebnoe kyno: ystoryia stanovlenyia, sovremennoe sostoianye, tendentsyy razvytyia dydaktycheskykh ydei [Educational film: the history of formation, current state, trends in the development of didactic ideas]. Voronezh: Voronezh. hos. un-t. [in Russian] 